\title{
Reserpine Changes the Dynamic State of Enkephalin Stores in Rat Striatum and Adrenal Medulla by Different Mechanisms ${ }^{1}$
}

\author{
ITALO MOCCHETTI, ALESSANDRO GUIDOTTI, JOAN P. SCHWARTZ, AND ERMINIO COSTA ${ }^{2}$ \\ Laboratory of Preclinical Pharmacology, National Institute of Mental Health, Saint Elizabeths Hospital, Washington, D.C. 20032
}

\begin{abstract}
The administration of reserpine increases enkephalin content in rat striatum and adrenal medulla. In order to investigate the mechanisms operative in this increase, we have studied in vivo the dynamic state of enkephalin stores by determining the content of proenkephalin mRNA, enkephalin precursors, and enkephalins in rats receiving reserpine. We measured proenkephalin mRNA by using a CDNA probe for human proenkephalin mRNA which hybridizes to the same species of mRNA either in the brain or in adrenal medulla. (Met $^{5}$ )-Enkephalin-Arg ${ }^{6}-$ Phe $^{7}$, as well as the high and low molecular weight forms of the enkephalins separated by Sephadex G-75 column chromatography, were measured by radioimmunoassay.

Reserpine ( $2 \mathrm{mg} / \mathrm{kg}$, i.p., repeated daily for two consecutive days) led 3 to 5 days later to an increase in the striatal content of proenkephalin mRNA as well as high and low molecular weight peptides containing enkephalin. The same treatment produced, in adrenal medulla, a shift from higher molecular weight to lower molecular weight enkephalin-containing peptides, an increase of enkephalin peptides, and a decrease of proenkephalin mRNA content. The results in striatum suggest that resperine increases enkephalin synthesis by removing a tonic dopaminergic inhibition: those in adrenal medulla indicate that reserpine causes an accumulation of enkephalins by blocking the release and/or increasing the processing which may trigger a feedback-regulatory mechanism leading to a decrease in proenkephalin mRNA content.
\end{abstract}

Peptides derived from proenkephalin (proenkephalin A) are stored in specific brain neurons (Hökfelt et al., 1977; Yang et al., 1977; Sar et al., 1978) and in granules of chromaffin cells (Stern et al., 1979; Viveros et al., 1979; Yang et at., 1980) of adrenal medulla. Several lines of investigation suggest that the enkephalins may be released by trans-synaptic stimuli from both of these storage sites and may function as modulatory synaptic signals or circulating hormones, respectively. Drugs can be used as tools to perturb the steady state of various enkephalin stores: by studying the dynamic state changes ensuing after such perturbation, one can begin to analyze regulatory mecharnisins active for enkephalin stores. For instance, the demonstration that striatal enkephalin synthesis was increased following

Received February 19, 1985; Revised April 29, 1985;

Accepted May 3, 1985

' We wish to thank Drs. M. Comb and E. Herbert for providing pHPE-9, Ms. Sonja Lofstrandh for her technical assistance, and Ms. Sheila Hart for typing the manuscript

${ }^{2}$ To whom correspondence should be addressed. repeated daily injection of dopamine receptor antagonists (Hong et al., 1978; Sabol et al., 1983; Tang et al., 1983) led to the suggestion that dopaminergic tone reduces synthesis of enkephalin peptides in the striatum. Furthermore, the enkephalin stored in adrenal medulla is under the regulation of splanchnic innervation (Schultzberg et al., 1978; Hexum et al., 1980; Lewis et al., 1981; La Gamma et al., 1984): hence, pharmacological manipulation of this regulation can be a useful tool to study the trans-synaptic modulation of medullary enkephalin storage and release (Viveros et al., 1979, 1980; Wilson et al., 1981; Bohn et al., 1983).

Since enkephalins are synthesized as part of a high molecular weight (HMW) precursor, the steady state of these peptides cannot be readily studied with classic isotopic methods and requires the application of new methodologies. Recently, we have shown that, at steady state, the dynamics of enkephalin stores can be studied by determining simultaneously the content of mRNA coding for proenkephalin (PE) with a cDNA probe and the content of HMW and low molecular weight (LMW) enkephalin-containing peptides with radioimmunoassay (RIA) (Mocchetti, et al., 1985). These measurements allow us to determine whether changes in the rate of synthesis of either the mRNA or the precursor, or changes in the rate of precursor processing or in the rate of utilization of the peptide have occurred: these processes, taken together, we define as the dynamic state of the peptide, and we have previously shown that changes in any one of these steps are not necessarily reflected in a change in the peptide content per se. Haloperidol increased enkephalin formation, since it increased both PE mRNA and enkephalin content, whereas fenfluramine appeared to decrease enkephalin utilization since it increased enkephalin content without changing PE mRNA levels (Tang et al., 1983; Mocchetti et al., 1984b). This interpretation was supported by an increase in the striatal content of HMW and LMW forms of enkephalin, analyzed by Bio-Gel P-2 chromatography, enzymatic digestion, and RIA of the various peptide fractions (Mocchetti, et al., 1985). Since the action of haloperidol was shown to be limited to the striatal stores of enkephalin, it was inferred that a dopaminergic trans-synaptic regulation was dominant in striatum but not in other brain regions. The importance of such a mechanism is corroborated by the present report showing that reserpine affects striatal and adrenal medulla (Wilson et al., 1981; Bohn et al., 1983) stores of enkephalin differently, those differences deriving from an action of reserpine on the regulatory mechanisms specific to each tissue.

\section{Materials and Methods}

Treatment of animals. Male Sprague-Dawley rats (Zivic Miller, Allison Park, $P A$ ), weighing 200 to $250 \mathrm{gm}$, were injected subcutaneously for 2 days with $2 \mathrm{mg} / \mathrm{kg}$ (i.p.) of reserpine (Sigma Chemical Co., St. Louis, MO) and sacrificed 1,3 , or 5 days after the last injection. Control rats were injected with the vehicle $(0.1 \mathrm{~m}$ acetic acid) and sacrificed after a time interval equal to that of reserpine-treated animals. 
Animals were sacrificed by decapitation and the adrenal glands were removed within $2 \mathrm{~min}$. Brain regions were dissected according to the method of Glowinski and Iversen (1966).

Radioimmunoassay. Tissues were homogenized in approximately $10 \mathrm{vol}$ of ice-cold $1 \mathrm{M}$ acetic acid containing $20 \mathrm{~mm} \mathrm{HCl}$ and $0.1 \% \beta$-mercaptoethanol. An aliquot of the homogenate was assayed for protein according to the method of Lowry et al. (1951). Tissue homogenates were centrifuged at $20,000 \times g$ for $30 \mathrm{~min}$. The supernatant was lyophilized and reconstituted with RIA buffer $(0.1 \mathrm{~m}$ Tris- $\mathrm{HCl}, \mathrm{pH} 7.4,50 \mathrm{~mm} \mathrm{NaCl}, 0.1 \%$ bovine serum albumin, $0.1 \% \beta$-mercaptoethanol), and an aliquot was assayed for $\left(\mathrm{Met}^{5}\right)$ enkephalin-Arg ${ }^{6}-$ Phe $^{7}$ (MEAP) as previously described (Mocchetti et al., 1984a).

Gel filtration. Striata or adrenal glands from 10 rats were pooled and homogenized in approximately $10 \mathrm{vol}$ of ice-cold $1 \mathrm{M}$ acetic acid, containing $20 \mathrm{~mm} \mathrm{HCl}$ and $0.1 \% \beta$-mercaptoethanol. Aliquots were removed for protein determination and the samples were then centrifuged at $20,000 \times g$ for 30 $\mathrm{min}$. The enkephalins in the supernatant were adsorbed on a Sep-Pak (C18) cartridge; after washing with $10 \mathrm{ml}$ of water, the enkephalin peptides were eluted with $3 \mathrm{ml}$ of $60 \% n$-propanol and lyophilized. The residue was dissolved in $1 \mathrm{ml}$ of $1 \mathrm{M}$ acetic acid and chromatographed on a Sephadex G-75 column $(0.9 \times 60 \mathrm{~cm})$ equilibrated and eluted with $1 \mathrm{M}$ acetic acid. The flow rate was $0.1 \mathrm{ml} / \mathrm{min}$. The fractions $(1 \mathrm{ml})$ were lyophilized and the residue was resuspended in $0.1 \mathrm{M}$ Tris- $\mathrm{HCl}, \mathrm{pH} 7.6$.

An aliquot of each fraction was assayed for MEAP. The rest of the sample was incubated alone or with TPCK-trypsin (Sigma) $(10 \mu \mathrm{g} / \mathrm{ml}$ for $2.5 \mathrm{~h}$ at $37^{\circ} \mathrm{C}$ followed by carboxypeptidase B (Worthington Biochemical Corp., Freehold, $\mathrm{NJ})\left(1 \mu \mathrm{g} / \mathrm{ml}\right.$ for $30 \mathrm{~min}$ at $\left.37^{\circ} \mathrm{C}\right)$ : the enzymes were inactivated by boiling for $5 \mathrm{~min}$ (Quach et al., 1984). Fractions were then assayed for Metenkephalin (ME) as already described (Quach et al., 1984) with minor modifications. The RIA was carried out using the antibody at a dilution of $1: 21,000$ and $10,000 \mathrm{cpm}$ of $\left({ }^{125}\right)$-ME. The recovery of ME from MEAP standards subjected to identical enzymatic digestion ranged between 60 and $70 \%$.

PE mRNA assay. For measurement of PE mRNA in brain, tissue was processed and RNA gel blot analysis was carried out as previously described (Tang et al., 1983), using the Hinc II fragment (918 bp) of pHPE-9 (Comb et al., 1982).

Adrenal glands were homogenized in approximately 10 vol of $10 \mathrm{~mm}$ Tris$\mathrm{HCl}, \mathrm{pH} 7.5,5 \mathrm{~mm}$ EDTA, $1 \%$ sodium dodecyl sulfate, proteinase $\mathrm{K}(65 \mu \mathrm{g} /$ $\mathrm{ml}$ ). After incubation for $90 \mathrm{~min}$ at $42^{\circ} \mathrm{C}$, phenylmethylsulfonyl fluoride was added $(0.03 \% \mathrm{w} / \mathrm{v})$, and the samples were extracted twice with phenol:chloroform (1:1) and once with chloroform. The nucleic acids were precipitated with ethanol, dissolved in $50 \mu$ l of $10 \mathrm{~mm}$ Tris- $\mathrm{HCl}, \mathrm{pH} 7.5,5 \mathrm{~mm}$ EDTA, and $5 \mu \mathrm{l}$ were spotted onto a $2 \%$ agarose plate containing $150 \mathrm{~mm}$ $\mathrm{NaCl}, 0.5 \mu \mathrm{g} / \mathrm{ml}$ of ethidium bromide, which was used to measure total nucleic acids. The remainder of the sample was heated $15 \mathrm{~min}$ at $60^{\circ} \mathrm{C}$ with $30 \mu \mathrm{l}$ of $3 \mathrm{M} \mathrm{NaCl}, 0.34 \mathrm{M}$ citrate, $\mathrm{pH} 7$, and $20 \mu \mathrm{l}$ of formaldehyde $(37 \%)$ prior to spotting onto nitrocellulose paper using a Hybri-Dot Manifold (Bethesda Research Laboratories, Bethesda, MD).

The amount of total nucleic acids was determined by densitometric scan of a photographic negative of the gel or of the agarose-ethidium bromide plate. The estimate of the amount of RNA on the gel was always comparable to that obtained by reading the optical density of the samples at $260 \mathrm{~nm}$. To confirm the linearity of the agarose-ethidium bromide plate method used to quantitate nucleic acid, serial dilutions of tRNA were spotted on the plate to obtain a standard curve. The density was linear in the range from $20 \mathrm{ng}$ to $1 \mu \mathrm{g} / \mathrm{spot}$.

The values for PE mRNA are presented in units which are defined as the peak area for PE probe hybridization per peak area for total RNA per sample. These units are dependent on a number of factors such as the amount of RNA per sample, the specific activity of the nick-translated probe, and the number of days of exposure of the autoradiogram. RNA gel blot and dotblot techniques thus provide a relative quantitation within an experiment. The control striatal PE mRNA content has been set equal to 1 and other samples calculated relative to it.

\section{Results}

Poly(A)-RNA was extracted from various brain regions of rats receiving reserpine $(2 \mathrm{mg} / \mathrm{kg})$ on two consecutive days and decapitated 1,3 , or 5 days after the last injection. Reserpine treatment resulted in a selective increase in the PE mRNA content of striatum (Fig. 1). This increase was seen in rats sacrificed 3 to 5 days after the last injection of reserpine but not in those decapitated after 1 day (Table I). Striatal MEAP content was increased 3 and 5 days after the last injection of reserpine (Table I). No changes were observed in other brain regions.

In order to characterize further the MEAP-like immunoreactivity, striatal extracts were chromatographed on a Sephadex G-75 column
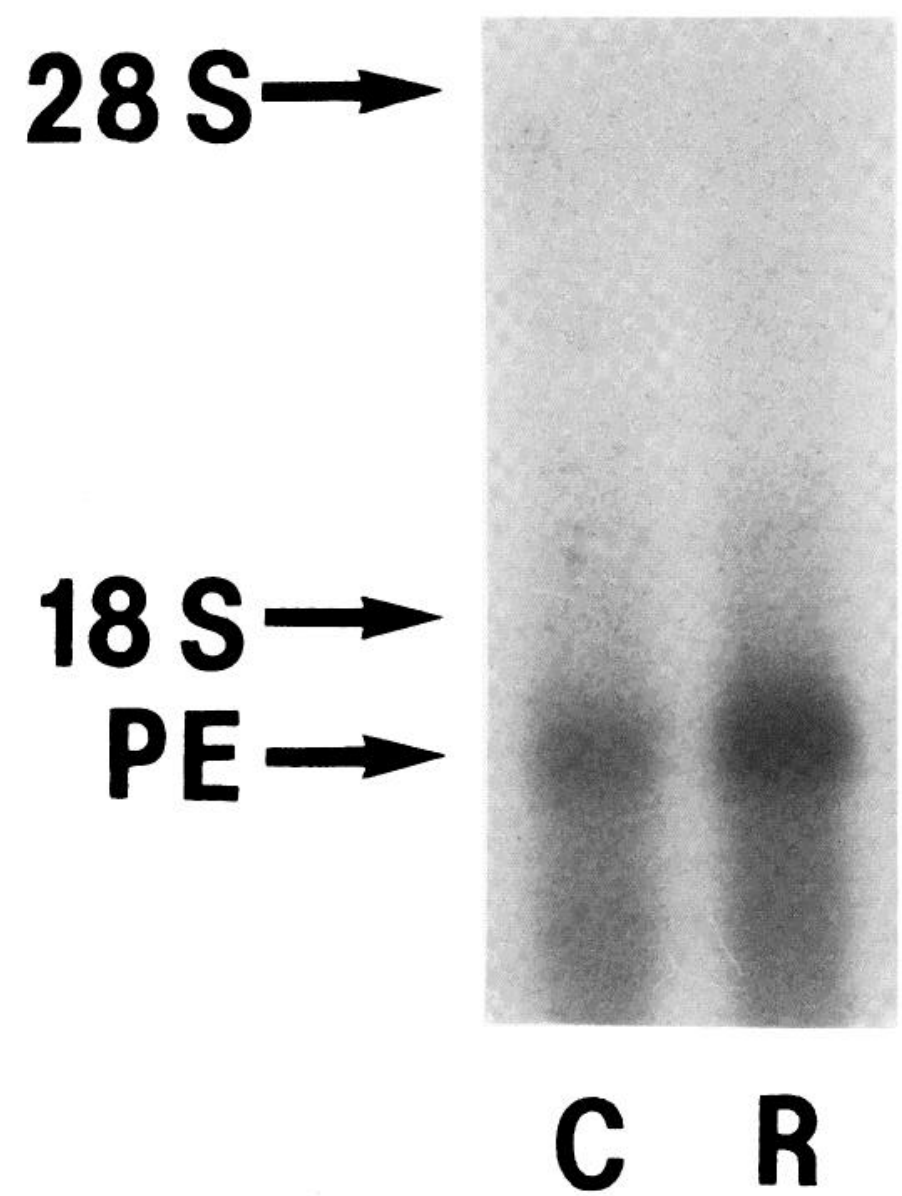

Figure 1. RNA gel blot hybridization analysis of strial PE mRNA. Animals were treated with vehicle $(C)$ or reserpine $(R)$ and sacrificed 3 days after the last injection. Poly(A)-RNA was extracted from striatum, separated on a formaldehyde-agarose gel ( $18 \mu \mathrm{g}$ of RNA in control; $17 \mu \mathrm{g}$ in reserpine lane), blotted onto nitrocellulose paper, and hybridized with a ${ }^{32} \mathrm{P}$-cDNA probe for PE mRNA as described under "Materials and Methods." The figure shows the autoradiogram. Ribosomal RNAs (18 S and $28 \mathrm{~S}$ ) were used as size markers. PE mRNA migrates with an apparent size corresponding to 1400 bases.

TABLE I

Effect of reserpine on PE MRNA and MEAP content in rat striatum

Rats were treated wtih $2 \mathrm{mg} / \mathrm{kg}$ (s.c.) of reserpine for 2 days and sacrificed 1,3 , or 5 days after the last injection. Data for MEAP content are the mean \pm SEM $(n=6)$ of two separate experiments. Data for PE mRNA are the mean \pm SD of two separate experiments.

\begin{tabular}{clcc}
\hline Day & Treatment & PE mRNA & MEAP \\
\hline \multirow{2}{*}{1} & Control & units & $n g / m g$ of protein \\
& Reserpine & $1.1 \pm 0.2$ & $4.0 \pm 0.2$ \\
\multirow{2}{*}{3} & Control & 1 & $4.6 \pm 0.3$ \\
& Reserpine & $1.8 \pm 0.2$ & $3.8 \pm 0.2$ \\
\multirow{2}{*}{5} & Control & 1 & $5.6 \pm 0.3^{a}$ \\
& Reserpine & $2.0 \pm 0.2$ & $3.4 \pm 0.2$ \\
& & & $6.2 \pm 0.1^{b}$ \\
\hline
\end{tabular}

${ }^{a} p<0.01$.

${ }^{\mathrm{b}} \mathrm{p}<0.001$. 
to separate the various molecular weight forms which contain MEAP. like immunoactivity. The results presented in Figure $2 A$ show that a striatal extract contains at least five molecular forms of MEAP-like immunoactivity (Fig. 2A, hatched bars), eluting as different peaks; the smallest molecular weight form elutes at the position of MEAP (fractions 45 to 56). The prccursor PE contains six copies of ME, two of which are carboxyl-extended, and one copy of Leu-enkephalin, and undergoes a series of proteolytic cleavages which produce intermediate-sized fragments containing ME sequences prior to the final products, the free peptides. Neither the MEAP nor the ME antibody recognizes all of the cryptic $M E$ sequences in the intermediate-sized peptides with equal affinity nor as well as they detect free ME or MEAP. Digestion of these intermediate-sized peptides with trypsin and carboxypeptidase $B$ releases all of the ME sequences. Therefore, after digestion with trypsin and carboxypeptidase $B$ and assay with ME antiserum, the quantity of ME-like immunoactivity in every fraction was increased (Fig. 2A, open bars) and one additional peak ( 20 kiladaltons) appeared. However, the ratio of LMW enkephalin immunoreactivity (fractions 45 to 56) to the larger enkephalin-containing peptide (ECP) immunoreactivity (fractions 14 to 44 ) did not change significantly as a result of enzymatic digestion: 54 before and 68 after the digestion. Thus, in striatum the most abundant form of enkephalin is the LMW species, whereas ECPs represent about 1 to $2 \%$ of the total immunoreactivity.

Separation by Sephadex G-75 chromatography of the ECPs present in striatal extracts from control rats and rats sacrificed 1,3 , and 5 days after the last injection of reserpine produced the results shown in Figure 3. All fractions were lyophilized, digested with trypsin-carboxypeptidase $B$, and assayed with an ME antiserum to provide the total ME immunoreactivity present. One day of reserpine treatment produced no significant change in the characteristics of the Sephadex G-75 profile relative to that of vehicle-treated rats (Fig. $3 A$ ). By 3 days (Fig. 3B), all peaks have increased; the ECPs (fractions 1 to 43 ) have increased $79 \%$ (84.6 ng total of ME versus 47.2) and the LMW enkephalins (fractions 44 to 60 ) have increased $51 \%$ (3500 ng total ME versus 2301). Five days after reserpine (Fig. $3 C$ ), the ECPs have increased $120 \%$ (103.1 ng total ME versus 46.9), whereas the LMW enkephalins have increased $97 \%$ (4341 ng total ME versus 2200).

In rat adrenal, the analysis of ECPs and of the LMW enkephalin peptides by Sephadex G-75 column chromatography (Fig. 2B) revealed a pattern different from that seen in striatum (Fig. 2A). Four peaks of MEAP-like immunoactivity were detected. After treatment with trypsin-carboxypeptidase $B$, the assay with ME antiserum revealed that the ME content of all of the peaks was increased: moreover, one additional peak could be detected. After enzymatic digestion, the ratio of ECP (fractions 1 to 44 ) to LMW enkephalins (fractions 45 to 60 ) increased trom 0.93 to 2.94. I hus, Pt processing in rat adrenal medulla differs from that in striatum (Lewis and Stern, 1983; Udenfriend and Kilpatrick, 1984), and the predominant form of medullary enkephalin is ECPs rather than LMW enkephalins, ECP being almost $75 \%$ of the total.

Since reserpine depletes adrenal medulla catecholamines, we studied the effect of reserpine on the medullary content of PE mRNA, FCP, and I MW enkephalin peptides. A dot-blot technique was used to measure PE mRNA. RNA from liver was used as a negative control and RNA from striatum was used as a positive control (Fig. 4). In the adrenal medulla, MEAP content was signifi-

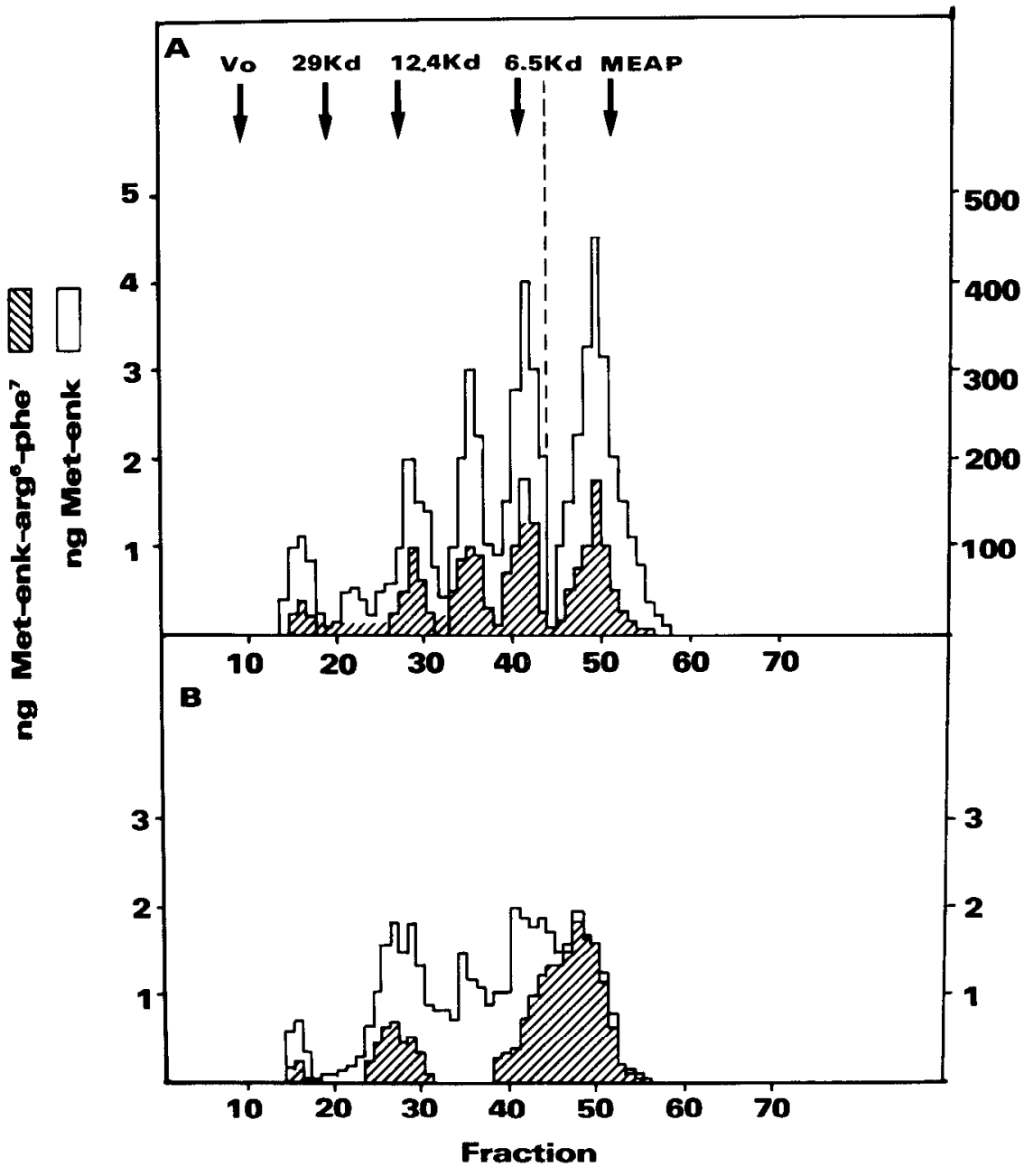

Figure 2. A, Sephadex G-75 chromatography of an acid extract of rat adrenal. One gram of tissue was homogenized and centrifuged, and the supcrnatant was lyophilized as described under "Materials and Methods." The lyophilizate was dissolved in $1 \mathrm{ml}$ of 1 $M$ acetic acid and passed over the column $(0.9 \times 60$ $\mathrm{cm})$, and $1-\mathrm{ml}$ fractions were collected. The fractions were lyophilized and dissolved in $0.1 \mathrm{M}$ Tris, $\mathrm{pH} 7.6$, and aliquots were assayed tor MEAP (hatched bars) or digested with trypsin-carboxypeptidase $B$ and assayed for ME (open bars) as described under "Materials and Methods." The scale on the left ordinate corresponds to fractions 1 to 44 ; the scale on the right ordinate corresponds to fractions 45 to 60 . The sum of MEAP immunoactivity for ECP (fractions 1 to 44 ) is $11.2 \mathrm{ng}$ and for LMW MEAP (fractions 45 to 60 ) it is $600 \mathrm{ng}$; the sum of ME immunoactivity for ECP is 40.1 $\mathrm{ng}$ and for ME, $2710 \mathrm{ng}$. The molecular weight markers used were: blue dextran (Vo), carbonic anhydrase (29 $K d)$, cytochrome $C(12.4 K d)$, aprotinin $(6.5 K d)$, and cobalt chloride, which eluted at the same position as 125/MEAP. This analysis was carried out twice with comparable results. $B$, Sephadex G.75 chromatography of an acid extract of rat striatum. The sample ( 475 $\mathrm{mg}$ of tissue) was processed as described for $A$. The sum of MEAP immunoactivity (hatched bars) for ECP (fractions 1 to 44 ) is $9.4 \mathrm{ng}$ and for LMW MEAP (fractions 45 to 60 ) it is $10.0 \mathrm{ng}$; the sum of ME immunoactivity (open bars) for ECP is $31.9 \mathrm{ng}$ and for LMW ME it is $10.8 \mathrm{ng}$. This analysis was carried out twice with comparable results. 
Figure 3. Sephadex G-75 chromatography of striatal extracts from control and reserpine-treated rats. Control or reserpine-treated rats were sacrificed 1 day $(A), 3$ days $(B)$, or 5 days $(C)$ after the last injection. The acid extract from $1 \mathrm{gm}$ of tissue was passed over the column, and fractions were digested with trypsin-carboxypeptidase B and assayed for ME as described under "Materials and Methods." The protein content of each homogenate was analyzed to ensure that all samples were equivalent in terms of protein before being applied to the column. The controls are represented as hatched bars and the reserpine-treated samples as open bars. The molecular weight markers are the same as those described in the legend to Figure $2 A$. The data are expressed as nanograms of MEequivalents. The scale on the left ordinate is for fractions 1 to 43 , and the scale on the right ordinate is for fractions 44 to 70 . Each experiment was repeated twice.

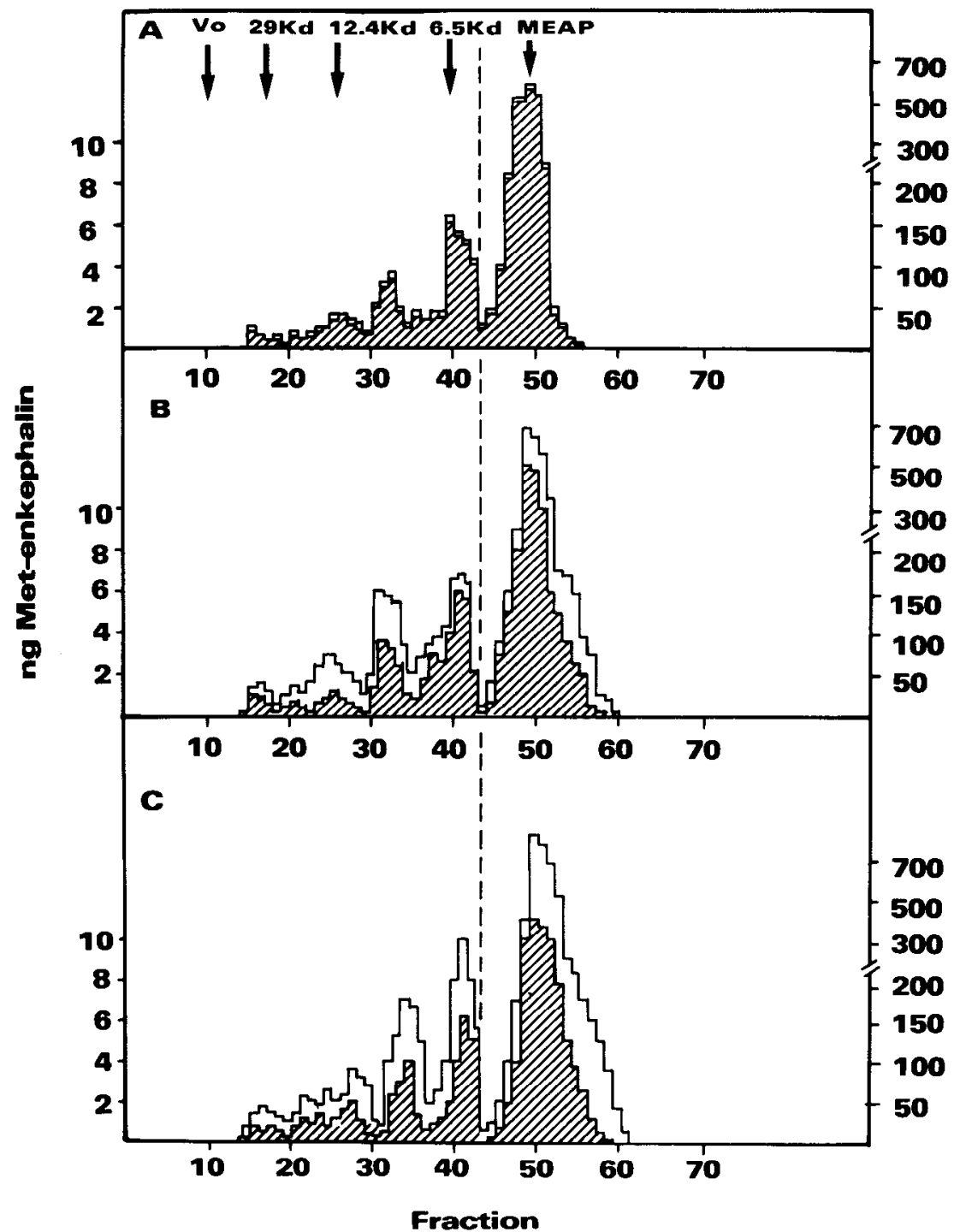

cantly increased 3 days after reserpine but had started to decline by 5 days (Table 11 ). In contrast, PE MRNA content started to decrease after 1 day and was maximally decreased by 3 days, at which time the peptide content was maximally increased (Table II). In order to interpret these results, adrenal medulla extracts from vehicle and reserpine-treated rats were analyzed by Sephadex G-75 chromatography (Fig. 5). All fractions were assayed for ME after trypsin-carboxypetidase $B$ digestion. There were no differences between the profiles for the vehicle and 1-day treated samples (Fig. $5 A$ ). After 3 days (Fig. 5B), the content of fractions 26 to 45 with intermediate molecular weight increased by $93 \%$ (48.9 ng versus 25.3) and the content of LMW enkephalin increased by $107 \%$ (31.5 ng versus 15.1). Five days after reserpine treatment (Fig. $5 C$ ), the HMW enkephalin immunoactivity (fractions 14 to 24) had decreased by $58 \%$ ( $2.2 \mathrm{ng}$ versus $5.2 \mathrm{ng}$ ), whereas the intermediate-sized ECPs and LMW enkephalins were still increased by $51 \%$ and $61 \%$, respectively (36.3 versus $24.1 \mathrm{ng}$ and 23.4 versus $14.5 \mathrm{ng}$ ).

\section{Discussion}

Several laboratories have reported that the enkephalin content of both striatum and adrenal medulla is increased after reserpine administration (Hong et al., 1979; Wilson et al., 1980; Bohn et al.,
1983) and have inferred that this drug enhances enkephalin synthesis in both tissues. Although reserpine could enhance striatal enkephalin synthesis by suppressing a tonic dopaminergic inhibition and thereby exerting a trans-synaptic action, it was not clear what mechanism was operative in mediating reserpine effects on enkephalin synthesis in medulla, where the action of reserpine is in the same cells. To clarify these issues we have assessed the profile of the dynamic changes in enkephalin synthesis caused by reserpine in medulla and striatum. In striatum, reserpine caused a rise in PF mRNA, in the HMW enkephalin precursors, and the LMW enkephalins. These changes occurred several days following termination of reserpine treatment, whereas no changes were observed $24 \mathrm{~h}$ after the last injection of reserpine. By the third day, the PE mRNA content was increased maximally, the ECPs were increased by $80 \%$, and there was a small increase in the content of LMW enkephalins. By the fifth day, striatal PE mRNA remained elevated, striatal ECPs had increased another $50 \%$, and LMW enkephalins were twice the control levels. Thus, reserpine increases striatal PE mRNA via a trans-synaptic effect by reducing dopaminergic tonic inhibition, possibly bringing about a stimulation of PE gene transcription. The specific mRNA thus formed is translated into PE and processed first to CCPS and finally to LMW enkephalins. The time delay between 

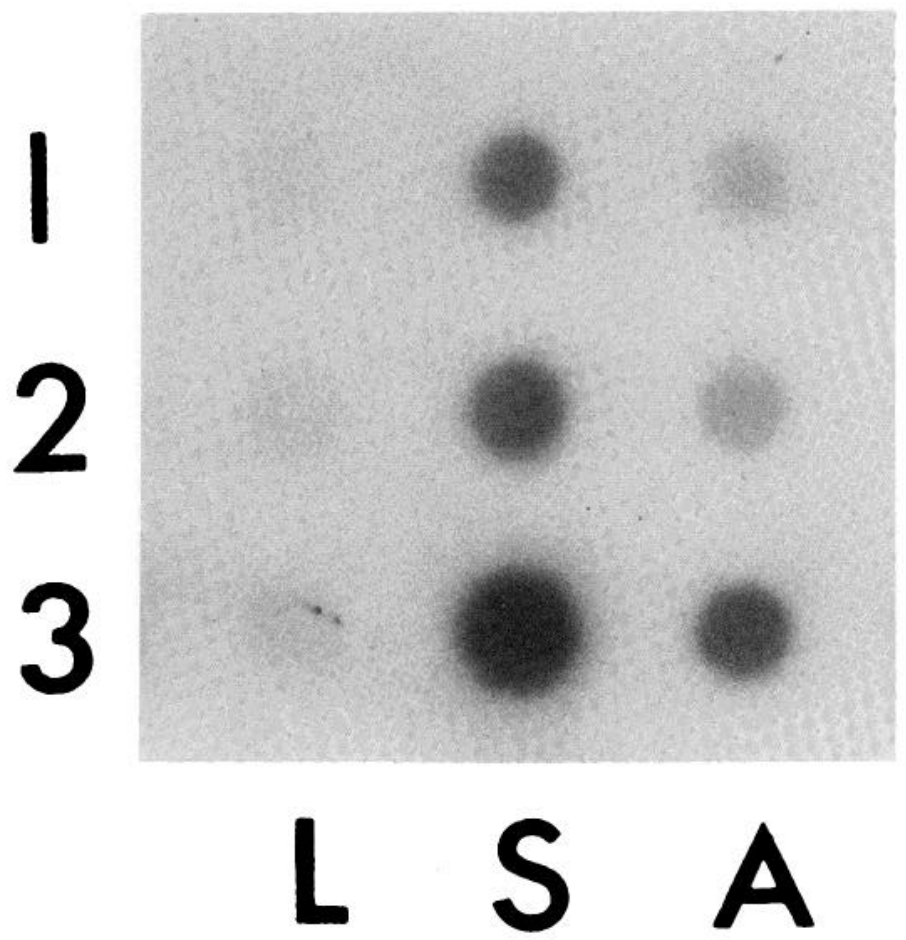

Figure 4. Dot-blot hybridization analysis of RNA from rat liver, striatum, and adrenal medulla. RNA was extracted from rat liver $(L)$, striatum $(S)$, and adrenal medulla $(A)$, according to the technique described under "Materials and Methods." For each sample, $50 \mu \mathrm{l}$, containing $2 \mu \mathrm{g}(1), 5 \mu \mathrm{g}(2)$, or 10 $\mu \mathrm{g}(3)$ of total nucleic acid, were spotted onto nitrocellulose paper using a Hybri-dot manifold. The blot was hybridized with a ${ }^{32} \mathrm{P}-\mathrm{CDNA}$ probe for PE mRNA. The figure shows the autoradiogram obtained.

\section{TABLE ॥}

Effect of reserpine on PE MRNA and MEAP content in rat adrenal medulla Rats were treated with $2 \mathrm{mg} / \mathrm{kg}$ (s.c.) of reserpine for 2 days and sacrificed 1,3 , or 5 days after the last injection. Data for PE mRNA content are the mean $\pm \operatorname{SEM}(n=6)$ from two experiments. Adrenal PE mRNA content was calculated relative to control striatum from the same dot blot, which was set equal to 1.0. Data for MEAP are mean $\pm \operatorname{SEM}(n=5)$ from one experiment, which was repeated once.

\begin{tabular}{clcl}
\hline Day & Treatment & PE mRNA & \multicolumn{1}{c}{ MEAP } \\
\hline \multirow{2}{*}{1} & Control & $0.16 \pm 0.03$ & $0.47 \pm 0.04$ \\
& Reserpine & $0.11 \pm 0.02$ & $0.46 \pm 0.02$ \\
\multirow{2}{*}{3} & Control & $0.15 \pm 0.02$ & $0.40 \pm 0.02$ \\
& Reserpine & $0.04 \pm 0.01^{a}$ & $0.81 \pm 0.03^{a}$ \\
\multirow{2}{*}{5} & Control & $0.17 \pm 0.02$ & $0.48 \pm 0.04$ \\
& Reserpine & $0.09 \pm 0.01^{a}$ & $0.66 \pm 0.03^{a, b}$ \\
\hline
\end{tabular}

${ }^{a} p<0.05$ versus its control.

${ }^{b} p<0.01$ versus the 3 -day reserpine MEAP

the increase in striatal mRNA and that in translation products is comparable to that seen in chromaffin cells (Quach et al., 1984). In addition, these results corroborate our previous observation that haloperidol, a dopaminergic receptor antagonist, increases striatal enkephalin synthesis as indicated by the increase of PE MRNA content and that of both HMW and LMW enkephalin peptides (Tang et al., 1983; Mocchetti et al., 1985). Also with haloperidol, there is a latency of three to four days for the increase in enkephalin synthesis
(Mocchetti, et al., 1985). Thus, a lasting blockade of striatal dopaminergic transmission, whether by haloperidol or reserpine, enhances via a trans-synaptic mechanism the synthesis of striatal PE.

The question was then whether reserpine would increase enkephalin synthesis in adrenal medulla through its depleting action on catecholamine stores, since enkephalins are co-localized with catecholamines in the granules of chromaffin cells (Viveros et al., 1979), the site of reserpine action. This possibility was in keeping with the lack of haloperidol action on the dynamic equilibrium of enkephalin stores in adrenal medulla (I. Mocchetti, unpublished results). Examination of the profile of reserpine action on the dynamic equilibrium of medullary enkephalins demonstrated that the reserpine effect in adrenal medulla was quite different from that in the striatum. Medullary PE mRNA decreased after reserpine administration: the extent of the decrease was slight $24 \mathrm{hr}$ after the last injection and reached a maximal value (73\%) 3 days after the last injection of reserpine. At 5 days PE mRNA content had begun to recover. Although the medullary content of LMW enkephalin had increased by 3 days, chromatographic analysis (Fig. 5) revealed that this increase in LMW enkephalin peptides was associated with a concomitant loss of HMW ECPs. Thus, in the adrenal medulla the response to reserpine treatment is a loss of PE mRNA accompanied by increased conversion of ECPs to LMW enkephalins. Similar results have been obtained in chromaffin cell cultures (Eiden et al., 1984; Naranjo et al., 1984). Several mechanisms might be postulated to explain these results. Preliminary evidence from our laboratory $(H$. Kageyama, unpublished results) suggests that reserpine blocks the release of enkephalin peptides from chromaffin cells, an effect which may be related to its blockade of the catecholamine transporter in the granules (Johnson and Scarpa, 1979; Deupree and Weaver, 1984). This decrease in enkephalin utilization, and the resultant intracellular accumulation of the peptide, might activate an intracellular negative feedback regulation whereby PE mRNA synthesis is turned off. Other alternatives are that reserpine might stimulate the rate of PE MRNA degradation or the rate of PE processing, which when coupled with a decreased rate of release would result in an increase of the content of LMW biologically active enkephalins.

Our results with reserpine provide further support for the concept that, although the enkephalin peptides are co-localized with catecholamines, and specifically with epinephrine in bovine adrenal medulla (Livett et al., 1982; Lang et al., 1983), their synthesis is not necessarily co-regulated. Agents which act via a stimulation of intracellular cyclic AMP do increase synthesis of both tyrosine hydroxylase and PE in chromaffin cells (Kumakura et al., 1979; Eiden et al., 1984; Quach et al., 1984). However, splanchnic denervation results in a loss of catechoamines but an increase of enkephalin immunoreactivity (Lewis et al., 1981; Bohn et al., 1983; Fleminger et al., 1984; La Gamma et al., 1984) as does reserpine (Bohn et al., 1983; Eiden et al., 1984; Naranjo et al., 1984). Impulse activity is also reported to have differential effects (La Gamma et al., 1984).

In conclusion, the present studies have allowed us to differentiate two mechanisms whereby reserpine can increase the enkephalin peptide content in adrenal medulla and striatum. A trans-synaptic tonic inhibition of striatal enkephalin synthesis is mediated by the dopaminergic innervation; reserpine, by depleting dopamine, acts trans-synaptically to reduce this tonic inhibition of the enkephalinergic neuron, thereby increasing PE mRNA transcription and enkephalin biosynthesis. In the adrenal medulla, however, reserpine is known to act directly on chromaffin cell granules (Johnson and Scarpa, 1979; Deupree and Weaver, 1984), which contain both the catecholamines and the enkephalin peptides. Along with the depletion of catecholamines due to blockade of reuptake, there is an increase in the content of enkephalin peptides associated with a loss of PE mRNA and enkephalin precursor peptides. Further work will be required to determine the precise mechanism of action whereby reserpine acts in adrenal chromaffin cells to decrease PE MRNA while increasing enkephalin peptide content. 
Figure 5. Sephadex G-75 chromatography of adrenal extracts from control and reserpine-treated rats. Control or reserpine-treated rats were sacrificed 1 day $(A), 3$ days $(B)$, or 5 days $(C)$ after the last injection. The acid extract from $400 \mathrm{mg}$ of tissue was passed over the column, and fractions were digested with trypsin-carboxypeptidase $B$ and assayed for ME as described under "Materials and Methods." The data are expressed as nanograms of ME-equivalents per fraction. The protein content of each homogenate was analyzed to ensure that all samples were equivalent in terms of protein before being applied to the column. The controls are represented as hatched bars and the reserpine-treated samples as open bars. The molecular weight markers are the same as those described in the legend to Figure $2 A$. Each experiment was repeated twice.

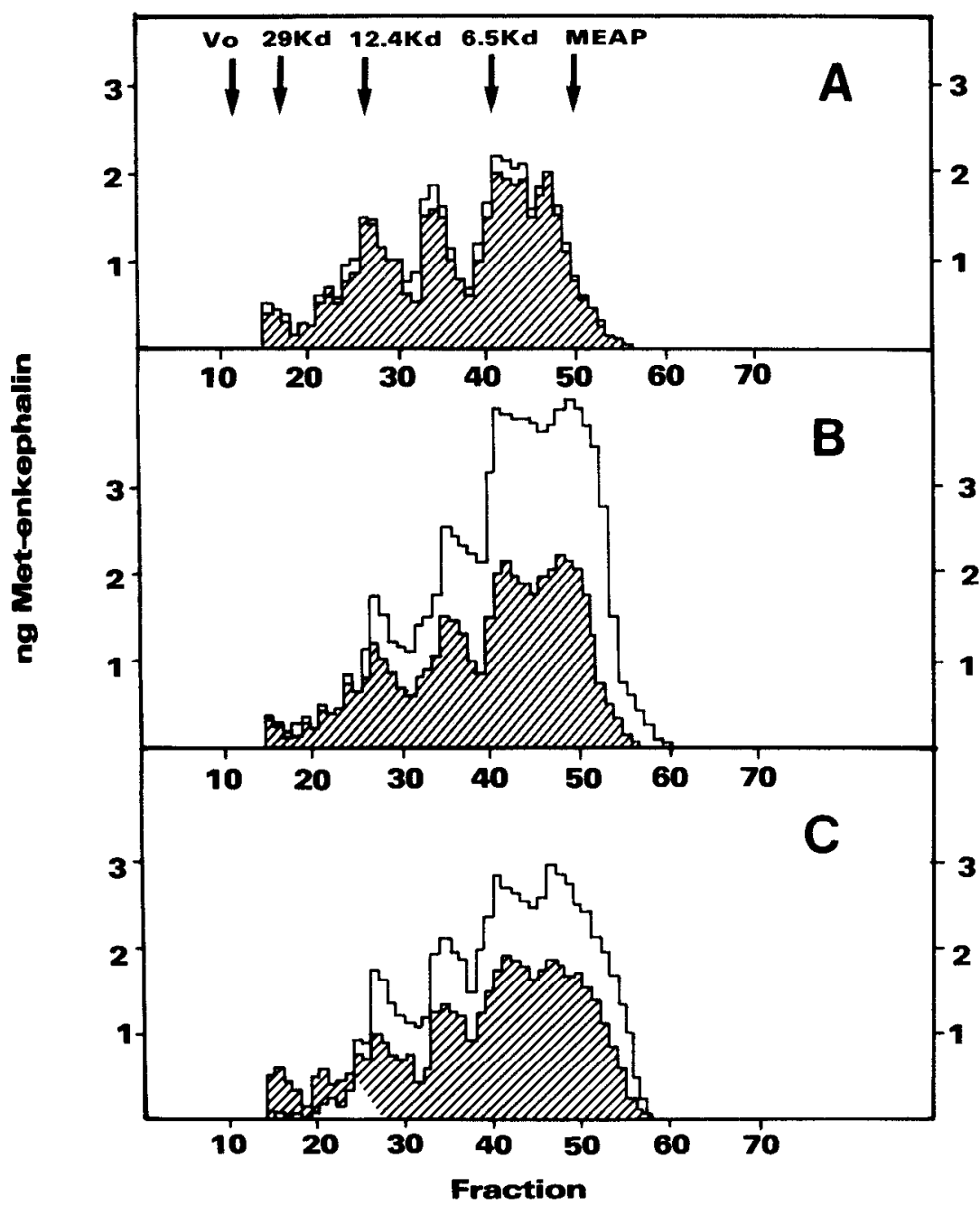

Hong, J. S., H. -Y. T. Yang, J. C. Gillin, W. Fratta, and E. Costa (1979) Participation of $\left(\right.$ Met $\left.^{5}\right)$-enkephalin in the action of antipsychotic drugs. In Endorphins in Mental Health Research, E. Usdin, W. E. Bunney, Jr., and N. S Kline, eds., pp. 105-114, Macmillan Press, London.

Johnson, R. G., and A. Scarpa (1979) Protonmotive force and catecholamine transport in isolated chromaffin granules. J. Biol. Chem. 254: 3750-3760.

Kumakura, K., A. Guidotti, and E. Costa (1979) Primary cultures of chromaffin cells: Molecular mechanisms for the induction of tyrosine hydroxylase mediated by 8-Br-cyclic AMP. Mol. Pharmacol. 16: 865-876.

La Garmma, E. F., J. E. Adler, and I. B. Black (1984) Impuise activity differentially regulates (leu)enkephalin and catecholamine characters in the adrenal medulla. Science 224: 1102-1104.

Lang, R. E., G. Taugner, W. Gaida, D. Ganten, K. Kraft, Th. Unger, and I. Wunderlich (1983) Evidence against co-storage of enkephalins with noradrenaline in bovine adrenal medullary granules. Eur. J. Pharmacol. 86 : $117-120$

Lewis, R. V., and A. S. Stern (1983) Biosynthesis of the enkephalins and enkephalin-containing polypeptides Annu. Rev Pharmacol. Toxicol. 23 353-372.

Lewis, R. V., A. S. Stern, D. L. Kilpatrick, L. D. Gerber, J. Rossier, S. Stein, and S. Udenfricnd (1981) Marked increases in large enkephalin-containing polypeptides in the rat adrenal gland following denervation. J. Neurosci. 1: $80-82$.

Livett, B. G., R. Day, R. P. Elde, and P. R. C. Howe (1982) Co-storage of enkephalins and adrenaline in the bovine adrenal medulla. Neuroscience 7: $1323-1332$.

Lowry, O. H., N. J. Rosebrough, A. L. Farr, and R. J. Randall (1951) Protein measurement with the Folin phenol reagent. J. Biol. Chem. 193: 265-275.

Mocchetti, I., O. Giorgi, J. P. Schwartz, and E. Costa (1984a) A reduction of the tone of 5-hydroxytryptamine neurons decreases utilization rates of striatal and hypothalamic enkephalins. Eur. J. Pharmacol. 106: 427-430. 
Mocchetti, I., J. P. Schwartz, and E. Costa (1984b) Studies of brain neuropeptide dynamics utilizing cDNA probes: Pharmacological implications. In Physiological and Pharmacological Control of Nervous System Development, F. Caciagli, ed., pp. 77-80, Elsevier Biomedical Press, Amsterdam.

Mocchetti, I., J.P. Schwartz, and E. Costa (1985) Use of mRNA hybridization and radioimmunoassay to study mechanisms of drug-induced accumulation of enkephalins in rat brain structures. Mol. Pharmacol., 28: 86-91.

Naranjo, J. R., I. Mocchetti, H. Kageyama, A. Guidotti, J. P. Schwartz, and E. Costa (1984) Action of reserpine on met $^{5}$-enkephalin utilization and proenkephalin mRNA content in adrenal medulla and striatum. Soc. Neurosci. Abstr. 10: 284

Quach, T. T., F. Tang, H. Kageyama, I. Mocchetti, A. Guidotti, J. L. Meek, E. Costa, and J. P. Schwartz (1984) Enkephalin biosynthesis in adrenal medulla: Modulation of proenkephalin mRNA content of cultured chromaffin cells by 8-Br-cyclic AMP. Mol. Pharmacol. 26: 255-260.

Sabol, S. L., K. Yoshikawa, and J. -S. Hong (1983) Regulation of methionineenkephalin precursor messenger RNA in rat striatum by haloperidol and lithium. Biochem. Biophys. Res. Commun. 113: 391-399.

Sar, M., W. E. Stumpf, R. J. Miller, K. -J. Chang, and P. Cuatrecasas (1978) Immunohistochemical localization of enkephalin in rat brain and spinal cord. J. Comp. Neurol. 182: 17-38.

Schultzberg, M., J. M. Lundberg, T. Hökfelt, J. Brandt, R. P. Elde, and M. Goldstein (1978) Enkephalin-like immunoreactivity in gland cells and nerve terminals of the adrenal medulla. Neuroscience 3: 1169-1186.

Stern, A. S., R. V. Lewis, S. Kimura, J. Rossier, L. D. Gerber, L. Brink, S. Stein, and S. Udenfriend (1979) Isolation of the opioid heptapeptide Metenkephalin $\mathrm{Arg}^{6}$, Phe ${ }^{7}$ from bovine adrenal medullary granules and striatum. Proc. Natl. Acad. Sci. U. S. A. 76: 6680-6683.
Tang, F., E. Costa, and J. P. Schwartz (1983) Increase of proenkephalin mRNA and enkephalin content of rat striatum after daily injections of haloperidol for 2 to 3 weeks. Proc. Natl. Acad. Sci. U. S. A. 80: $3841-$ 3844 .

Udenfriend, S., and D. L. Kilpatrick (1984) Proenkephalin and the products of its processing: Chemistry and biology. In The Peptides: Analysis, Synthesis, Biology, S. Udenfriend and J. Meienhofer, eds., pp. 25-68, Academic Press, Inc., New York.

Viveros, O. H., E. J. Diliberto, Jr., E. Hazum, and K. -J. Chang (1979) Opiatelike materials in the adrenal medulla: Evidence for storage and secretion with catecholamines. Mol. Pharmacol. 16: 1101-1108

Viveros, O. H., E. J. Diliberto, Jr., E. Hazum, and K. -J. Chang (1980) Enkephalins as possible adrenomedullary hormones: Storage, secretion and regulation of synthesis. In Neural Peptides and Neuronal Communication, E. Costa and M. Trabucchi, eds., pp. 191-204, Raven Press, New York

Wilson, S. P., K. -J. Chang, and O. H. Viveros (1980) Synthesis of enkephalins by adrenal medullary chromaffin cells: Reserpine increases incorporation of radiolabeled amino acids. Proc. Natl. Acad. Sci. U. S. A. 77: 43644368.

Wilson, S. P., M. M. Abou-Donia, K. -J. Chang, and O. H. Viveros (1981) Reserpine increases opiate-like peptide content and tyrosine hydroxylase activity in adrenal medullary chromaffin cells in culture. Neuroscience 6 : 71-79.

Yang, H. -Y. T., J. S. Hong, and E. Costa (1977) Regional distribution of leuand met-enkephalin in rat brain. Neuropharmacology 16: 303-307.

Yang, H. -Y. T., T. Hexum, and E. Costa (1980) Opioid peptides in adrenal gland. Life Sci. 27: 1119-1125. 